\title{
UN Convention on the Rights of the Child: "Where are we at in recognising children's rights in early childhood, three decades on ...?"
}

\section{Maryanne Theobald ${ }^{1}$}

Published online: 18 November 2019

(C) Springer Nature B.V. 2019

\section{Introduction}

This special issue of the International Journal of Early Childhood (IJEC) recognises the 30th anniversary since the rights of children in international law were acknowledged in the United Nations Convention on the Rights of the Child (UNCRC; United Nations 1989). Since that time, social reform agendas stemming from the Convention have been instrumental in addressing national and international policies in relation to the rights of children and youth. Broadly speaking, the UNCRC addresses children's interests across "the three Ps", covering children's rights to provision, protection and participation.

The early years are a "critical period for realizing children's rights" (United Nations 2006, p. 3). When UNCRC came into force in 1989, the Committee on the Rights of the Child was also established as was required by Article 43. This committee monitors progress on the implementation of the UNCRC and also applies a process by which issues of importance to the recognition of children's rights are investigated, either as specific provisions identified in UNCRC articles or general problems of implementation. Early childhood organisations and programs catering for children, aged birth to 8 years, at local, state and global levels have become more active in addressing young children's rights, resulting in recommendations for how adults are expected to engage with young children.

In this special issue, a range of articles from across the world are featured that explore how children's rights have been enacted in early childhood education, and the challenges and opportunities that are afforded to young children and their families within a children's rights agenda.

Maryanne Theobald

m.theobald@qut.edu.au

1 School of Early Childhood and Inclusive Education, Faculty of Education, Queensland University of Technology, Victoria Park Road, Kelvin Grove, QLD 4059, Australia 


\section{Why Focus on Children's Rights in Early Childhood?}

"General Comment No 7: Implementing child rights in early childhood" (GC7; United Nations 2006) provided initial directions to understand the diverse ways by which the rights of young children can be understood. The GC7 encourages early childhood institutions, policy makers and staff to promote and implement children's rights. Young children are rights holders, and yet their rights are often overlooked due to perceptions of immaturity. Early childhood is a time of rapid development during which the foundations for communication, connection and identity are built. Young children's experiences and development are "powerfully shaped" by cultural beliefs, family and community (United Nations 2006, p. 3). From an early age, children are "acutely sensitive to their surroundings" (p. 7) and understand others' emotions and behaviours as they build their identity in multiple ways. The family also play a significantly larger role in the lives of younger children. Early childhood is an optimal time to have a positive impact on a young child's well-being and acceptance by others with whom they interact.

Some signatories of the UNCRC, for example, in Nordic countries, have embraced rights-based perspectives as core to policy, curriculum and pedagogy. In those countries, young children are increasingly recognised as active participants in their communities, especially in early childhood programs. In other countries, children's rights, as the basis for early childhood policy and pedagogy, occur in pockets only, with lack of widespread adoption. Professionals working with young children across organisations and different types of programs can be instrumental in facilitating rights-based perspectives in policy, research and practice.

\section{Children's Rights in Early Childhood Education: Where are We at Now?}

While some advancement in the recognition of children's rights has been apparent, challenges remain, particularly in the areas of policy and practice in early childhood programs. Research on children's rights in early childhood suggests a paradox, in which tensions exist regarding the framing of rights-being individualistic or with a group-focussed standpoint. On the one hand, children's rights are proposed and respected for the benefit accrued to the individual. From this standpoint, there is acknowledgement that children have rights to make decisions about matters that affect them and to experience those rights in their daily lives (United Nations 1989). On the other hand, a group-focussed standpoint may exist, in which children's rights are underpinned by a democratic perspective. For example, implementation and education for children's rights can be linked to theoretical ideas about global citizenship (Pierce et al. 2010); an emphasis on the future (Correia et al. 2019; Zachrisen 2016); and preferred attitudes of selflessness and altruism (Brantefors and Quennerstedt 2016). The view of 
"benefit-for-the-greater-good" is often not seen as being relevant in the lives of young children. When opportunities for young children to exert their agency are associated with children being "responsible participants in society" (Brantefors and Quennerstedt 2016, p. 8), the potential benefit to society might be placed ahead of children's rights as individuals.

\section{Complexities in Individual and Group-Focused Standpoints on Children's Rights}

Four observations highlight the complexities of individualistic and group-focused standpoints on rights. The first observation relates to an individualistic standpoint on children's rights. While aiming to benefit children as individuals, UNCRC promoted children's rights as shared rights, rather than rights decreed to individuals in a self-interested manner. Rights are not absolute and cannot be exercised in ways that would harm the child or others (Alderson 2008).

A second observation is that children's rights are intertwined with adult knowledge and personal position. The rights movement has been successful in focusing on how children can be "effectively and ethically" involved (Tisdall 2015, p. 87). However, very young children, children living in poverty (see, for example, Lundy and O'Lynn 2019), children in vulnerable circumstances (see, for example, Alderson et al. 2017), or in contexts in which children and their families are marginalised, are not well positioned to enact rights. The knowledge and position of adults are particularly relevant in affording young children's rights to participation. The process for how children's rights might be enacted, and therefore experienced, is directly associated with "the outcome of how far decisions are acted on" (Alderson 2008, p. 80, original emphasis). Pedagogical approaches do not always attend to children's views and opportunities for participation, especially in the case of young children (Lansdown et al. 2014). Challenges in this area relate to constraints to do with organisational systems (Correia et al. 2019) and long-held debates regarding the developing capabilities of young children (Lansdown 2005). In this volume, Sirkko et al. (2019) challenge teachers to consider how their classroom practices may unintentionally reduce children's participation, contribution and agency.

A third observation involves the perceived relationship between children's rights and responsibility. There is an underlying assumption that children, in order to have rights recognised, must have some kind of responsibility associated with their allocation of such rights (Lundy and O'Lynn 2019). While young children are not always considered to be holders of rights and, therefore, often relieved of expectations of responsibilities, the rights of children "are not" contingent on obligations or responsibilities. As young children's lives become intertwined with adult lives, for example, through digital technologies and media, opportunities for exerting agency and experiencing responsibility are often promoted.

A fourth observation relates to the complexities that children's rights are underpinned by a democratic perspective. With this consideration, situations may arise in which decisions need to be made about whose rights are attended to, when those rights conflict with the rights of others. Do the rights of the many outweigh the rights of the few? (Johansson et al. 2016). While rights of the majority might seem to outweigh the 
rights of an individual, such thinking overlooks a key commitment about children's rights: that "rights are rights" and not indulgences. When some sacrifice is required, distribution of rights should be fair (Freeman 2017). The everyday interactions of young children, and their connections and communications with others, shape and build the values that they will hold about themselves, and the world around them.

\section{Children's Rights in Early Childhood Education: What's Missing?}

Despite calls for rights-based perspectives to be adopted in aspects of children's everyday lives (Theobald et al. 2011), there are no systematic frameworks to underpin the juxtaposition and embedding of young children's rights in early childhood education programs. Greater understanding of the relevant structuring of actions and events, in which children's rights can be embedded, would be worthwhile. With respect to research, a focus on the varying level of detail about events and actions that support recognition of children's rights in practice could be useful.

Fine-grained data and rich descriptions provide depth of understanding, often through small-scale studies, about children's views and experiences. Such a research approach is well-suited to the field of early childhood education. For example, Church and Bateman (2019), in this volume, present interactional analyses of naturalistic data, to investigate pedagogical approaches to child participation that show how teachers can build more learner-initiated experiences to support children's rights in everyday interactions. Mayne and Howitt (2019), in this volume, also investigate how meaningful research participation with young children can be developed through an interactive narrative process, while Knauf (2019) explores data about the nature and availability of play and learning materials in the physical environments of early childhood centres that promote children's rights to participation.

At a macro-scale, through larger-scale and/or longitudinal research, it is possible to explore how children experience and negotiate their rights across different contexts, spaces and time. Macro-views provide different understandings about how rights-based approaches can be implemented in early childhood education. Understanding how the world is observed, noticed and experienced by children across the contexts, in which they live, is the basis of "culture". The different ways of embedding rights across cultures might be researched. Other macro-approaches might track young children over time, as they become youth, to understand how recognition of rights over time impacts everyday lives; or explore how rights-based practices in early childhood environments differ, through cross-country analyses. Micro- and macro-investigations offer understandings of the "layers of intersubjective experiences, knowledges and interpretations" (Johansson and Berthelsen 2019, p. 139) within young children's lives.

\section{Policy and the Enactment of Children's Rights}

There is incongruence between policy initiatives and enactment of children's rights in early childhood. Early childhood research, policy and education would benefit from research that scrutinises how children's rights are incorporated in national and 
international policies, and steering documents, that focus on early childhood education. Such research may influence and impact by providing recommendations about how rights-based perspectives can become foundational in early childhood policy, curriculum and pedagogy.

\section{Recognising and Communicating Children's Rights}

Important work has been done to progress children's rights in early children education; however, more could be achieved. Globally, 64 million children of primary school age or younger do not access education (UNESCO Institute for Statistics 2019). As well, disparities exist in the quality of education programs accessed with more to be done to ensure quality in early childhood education programs (Lundy and O'Lynn 2019). Children's rights are not recognised when access to quality education is limited, especially when children are living in poverty, children are facing discrimination, and for children with disabilities.

Research that explores how young children's rights are recognised in communities and other spaces is welcome. Lee-Hammond and Jackson-Barrett (2019), in this volume, outline a framework of essential elements necessary for realising Indigenous children's linguistic rights. To progress this work, young children might be invited to investigate their own cultures and languages, particularly in education settings.

\section{Pedagogic Approaches for Incorporating Children's Rights}

Education programs that have a human rights focus require children to be involved as they have a right to have a say in matters that affect them, and to ensure that they are listened to and taken seriously (Brantefors and Quennerstedt 2016). A consensus on what participation can mean and how it can be best supported in childhood education is important (Lansdown et al. 2014). Clement (2019), in this volume, provides a review of how children's participation has been addressed in an early childhood education setting and what happens when children design and co-create a classroom space.

\section{New Forums or Spaces for Children's Rights Discussions}

Digital spaces are enabling opportunities for global discussions about children's rights. For example, Zanatta et al. (2019), in this volume, offer their reflections on using Twitter as a social forum to promote understanding of children's rights with professionals across disciplines and countries. This research identifies how media forums (existing and emerging) might be embraced and used to invigorate global attention and awareness on the issues of children's rights. Innovative methods presented provide blueprints for future work in this area. 


\section{Conclusions}

The studies included in this volume highlight some of the complexities and intricacies of implementing and researching children's rights through familiar and innovative methods. These studies provide rich description and various practice applications to present snapshots of current research on children's rights in early childhood education, internationally.

Importantly, this special issue begins with a Bulletin Board, an OMEP policy forum authored by Engdahl (2019). It focuses on how UNCRC has been recognised across national contexts and the current status of the UNCRC in legislation, policy and ECE curricula across the globe. Engdahl endorses OMEP's ongoing commitment to the implementation and realisation of young children's rights.

\section{References}

Alderson, P. (2008). Young children's rights: Exploring beliefs, principles and practice (2nd ed.). London: Jessica Kingsley.

Alderson, P., Hawthorne, J., \& Killen, M. (2017). The participation rights of premature babies. In U. Kilkelly (Ed.), Children's rights (pp. 91-106). London: Routledge.

Brantefors, L., \& Quennerstedt, A. (2016). Teaching and learning children's human rights: A research synthesis. Cogent Education, 3(1), 1247610. https://doi.org/10.1080/2331186X.2016.1247610.

Church, A., \& Bateman, A. (2019). Children's right to participate: How can teachers extend childinitiated learning sequences. International Journal of Early Childhood. https://doi.org/10.1007/ s13158-019-00250-7.

Clement, J. (2019). Spatially democratic pedagogy: Children's design and co-creation of classroom space. International Journal of Early Childhood. https://doi.org/10.1007/s13158-019-00253-4.

Correia, N., Camilo, C., Aguiar, C., \& Amaro, F. (2019). Children's right to participate in early childhood education settings: A systematic review. Children and Youth Services Review, 100, 76-88.

Engdahl, I. (2019). OMEP policy forum: UN convention on the rights of the child has become policy in many countries. International Journal of Early Childhood. https://doi.org/10.1007/s1315 8-019-00257-0.

Freeman, M. (2017). The value and values of children's rights. In U. Kilkelly (Ed.), Children's rights (pp. 91-106). London: Routledge.

Johansson, E., \& Berthelsen, D. (2019). Peer culture and mealtimes with toddlers in a child care context: "Put your bowls on the table. It's not a toy". In S. Fass, D. Kasüschke, E. Nitecki, M. Urban, \& Wasmuth (Eds.), Globalization, transformation and cultures in early childhood education and care. Cham: Palgrave Macmillan. https://doi.org/10.1007/978-3-030-27119-0_9.

Johansson, E., Emilson, A., Röthle, M., Puroila, A. M., Broström, S., \& Einarsdóttir, J. (2016). Individual and collective rights expressed in educator and child interactions in Nordic preschools. International Journal of Early Childhood, 48(2), 209-224.

Knauf, H. (2019). Physical environments of early childhood education centres: Facilitating and inhibiting factors supporting children's participation. International Journal of Early Childhood. https ://doi.org/10.1007/s13158-019-00254-3.

Lansdown, G. (2005). Can you hear me? The right of young children to participate in decisions affecting them. Working Paper 36. The Hague, The Netherlands: Bernard van Leer Foundation.

Lansdown, G., Jimerson, S. R., \& Shahroozi, R. (2014). Children's rights and school psychology: Children's right to participation. Journal of School Psychology, 52(1), 3-12.

Lee-Hammond, L., \& Jackson-Barrett, E. (2019). Indigenous children's linguistic rights in the twentyfirst century: Intentions and tensions in practice. International Journal of Early Childhood. https ://doi.org/10.1007/s13158-019-00251-6. 
Lundy, L., \& O’Lynn, P. (2019). The education rights of children. In U. Kilkelly \& T. Liefaad (Eds.), International human rights of children (pp. 259-276). Singapore: Springer.

Mayne, F., \& Howitt, C. (2019). Embedding young children's participation rights into research: How the interactive narrative approach enhances meaningful participation. International Journal of Early Childhood. https://doi.org/10.1007/s13158-019-00255-2.

Pierce, L., Reysen, S., \& Katzarska-Miller, I. (2010). The search for a definition of global citizenship. In Reysen, S. (Chair), Global citizenship: Americans within the world. Symposium conducted at the 54th Annual Meeting of the American Studies Texas Association of Texas, Commerce, Tx. Texas A\&M University - Commerce.

Sirkko, R., Kyrönlampi, T., \& Puroila, A.-M. (2019). Children's agency: Opportunities and constraints. International Journal of Early Childhood. https://doi.org/10.1007/s13158-019-00254-3.

Theobald, M., Danby, S., \& Ailwood, J. (2011). Child participation in the early years: Challenges for education. Australasian Journal of Early Childhood, 36(3), 19-26.

Tisdall, E. K. M. (2015). Participation, rights and 'participatory' methods. In A. Farrell, S. L. Kagan, \& E. K. M. Tisdall (Eds.), The SAGE handbook of early childhood research (pp. 73-88). London: SAGE.

UNESCO Institute for Statistics. (2019). Out of school children and youth. Geneva: United Nations Education, Scientific and Cultural Organisation (UNESCO). Retrieved from http://uis.unesco.org/en/ topic/out-school-children-and-youth.

United Nations. (1989). Convention on the Rights of the Child. Geneva: Office of High Commissioner for Human Rights (OHCHR). Retrieved from https://www.ohchr.org/EN/ProfessionalInterest/Pages /CRC.aspx.

United Nations. (2006). General comment No. 7: Implementing child rights in early childhood (CRC/C/ GC/7/Rev.1). Geneva: UN Office of High Commissioner for Human Rights (OHCHR). Retrieved from http://www2.ohchr.org/english/bodies/crc/docs/AdvanceVersions/GeneralComment7Rev1.pdf.

Zachrisen, B. (2016). The contribution of different patterns of teachers' interactions to young children's experiences of democratic values during play. International Journal of Early Childhood, 48(2), 179-192.

Zanatta, F., Martinez Sainz, G., \& Gillett-Swan, J. (2019). A critical realist reflection on the use of social media as third space for rights education in early childhood. International Journal of Early Childhood. https://doi.org/10.1007/s13158-019-00253-4.

Publisher's Note Springer Nature remains neutral with regard to jurisdictional claims in published maps and institutional affiliations. 